\title{
Evaluation of Imminent Fire Hazards of Inheritance Ancestral Temple and Mansion in Georgetown, Penang
}

\author{
M.A. Othuman Mydin ${ }^{1}$, N.A Agus Salim², N. Md. Sani ${ }^{3}$, Y.Y. Khaw ${ }^{4}$ \\ ${ }^{1,3,4}$ School of Housing, Building and Planning, Universiti Sains Malaysia, 11800 Penang, Malaysia \\ ${ }^{2}$ Faculty of Architecture, Planning and Surveying, UiTM Perak, Seri Iskandar Campus, 32610, Seri \\ Iskandar, Perak, Malaysia
}

\begin{abstract}
Fire hazards of the inheritance buildings are often been neglected, causing fire to take place. Most of the heritage buildings are of large scale, flammable priceless contents and large numbers of visitors, however, the existing structures are weak in fire resistance. There are a few factors that contribute to the fire in these unique yet vulnerable structures Therefore, fire risk assessment plays an important role as many historic buildings in Penang are significant in their architectural value and historically importantt and their destructions by fire are great irreplaceable losses. Thus, this study is intended to identify the current fire emergency plan of heritage temples and mansions in Penang which includes 4 buildings such as Khoo Kongsi, Cheah Kongsi, Hock Teik Chen Shin Temple and Teochew Temple. The possible fire risks of these heritage buildings will be identified and evaluated comprehensively. The previous fire cases will be considered as well in order to discover the common factors contributing to the fire cases at heritage buildings. Time and again, people do not record their findings upon completing the fire risk assessment. Hence this particular research will prepare a complete record of the fire risk assessment. Having a fire risk assessment in the heritage building in Penang can be an interesting study to find out the current situation of heritage building fire protection awareness.
\end{abstract}

\section{Introduction}

As most of the heritage buildings in Penang were built prior to the formulation of Uniform Building by Laws 1984, these heritage buildings are not subjected to the provision of fire safety requirement provided by the by-law [1]. Many of these heritage buildings were built without much thought given to fire protection and resistance [2]. It is broadly acknowledged that fire is one of the furthermost threats not only to a building's occupants but also to the building's fabric and contents $[3,4]$. Fire has long been an adversary of heritage buildings and their structures, with some older structures falling victim several times [5]. Salleh pointed out several heritage buildings which were badly damaged or burnt down by fire in Malaysia, including the People Museum, Melaka in 2001, Rumah Pak Ali, Gombak in 2003 and Sarawak Club, Kuching in 2006 [6].

Another significant heritage building fire mishap happened on 11th December 2008, when fire destroyed 7 shops [7]. In Malacca, similar fire case reported to take place on $7^{\text {th }}$ August 2012, whereby a century old Lido theatre, had burnt down to ashes [8]. The blaze, which occurred just past 
midnight, destroyed most of the structure of the city's landmark in Jalan Kee Ann. Although the building no longer housed the theatre but a supermarket instead, but its name was retained due to its historic value. The fire demolished everything in it, causing severe loss to the owner [9].

Recently fire outbreak also reported in Jalan CY Choy, Georgetown. On February 24th, 2013 , a row of 10 shop houses went down in flames on the Chap Goh Meh celebration in the evening. It was fortunate that no one was injured in the incident. The damages were estimated to be more than RM1 million. According to Beach Street fire station head, Ismail Mohd Zain, six engines from nearby fire stations rushed to the scene after a distress call was received at $7.55 \mathrm{pm}$. According to Ismail, the fire raged as the pre-war properties were mainly constructed from wood, causing the fire to spread quickly [10].

Efforts should be made to improve fire protection and resistance at historic buildings to make certain that they are safe from the danger of fire with the concern of preserving the buildings' fabric without destroying or changing the features of existing buildings [11, 12]. In order to complete this research, 4 heritage religious buildings in Penang will be chosen as samples to carry out further investigation.

\section{Case Study}

As a mean to provide more understanding and to perform this research more accurately, 4 ancestral temples, namely Khoo Kongsi, Cheah Kongsi, Penang Teochew Association, and Hock Teik Cheng Sin Temple, in Penang were identified as case study of this research as been shown in Fig. 1.

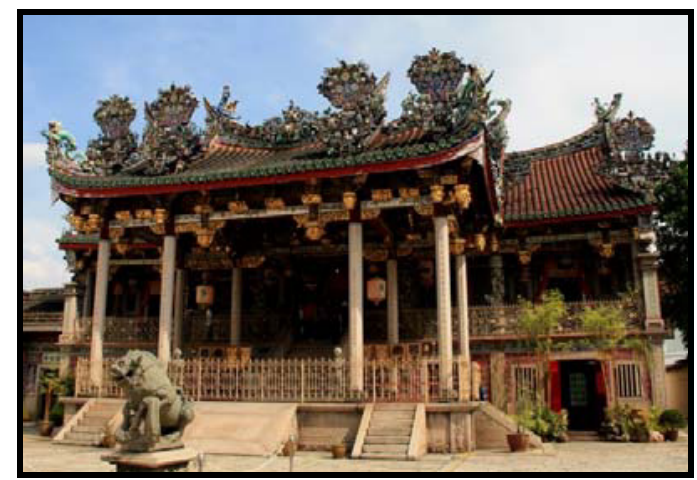

(a) Khoo Kongsi building

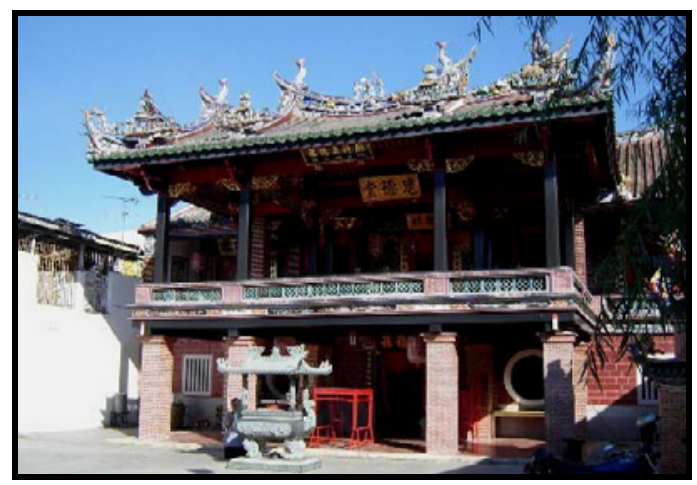

(c) Hock Teik Chen Shin Temple

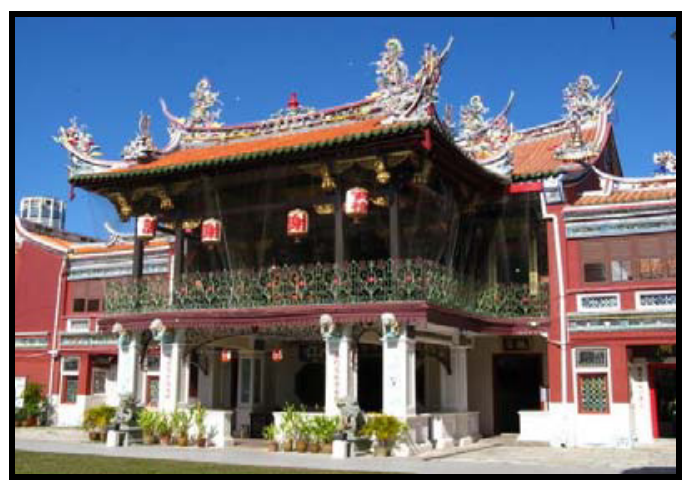

(b) Cheah Kongsi building

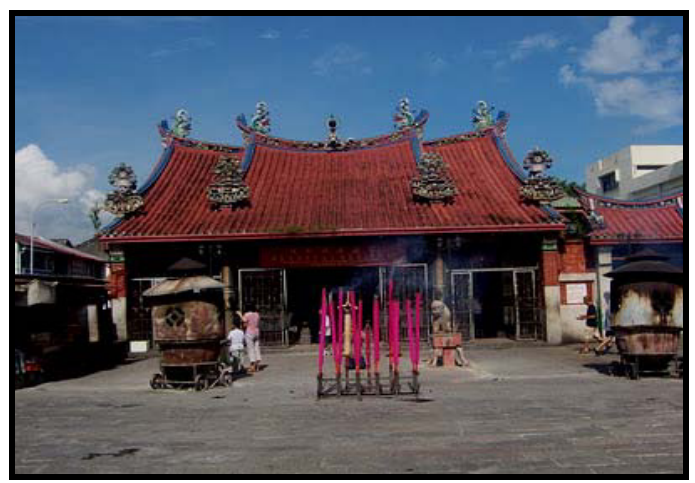

(d) Teochew Temple

Figure 1: Buildings for case study. 
All of the aforementioned temples age over 200 years old. Currently, these heritage buildings are used as a clan house and an ancestral temple for the current generation to worship their ancestral. Khoo Kongsi has the largest area as compared to other temples, with a remarkable area of 97,035 sq $\mathrm{ft}$ whereas others are only around $14,000 \mathrm{sq} f t$ to 20,000 sq. $\mathrm{ft}$. Table 1 summarized the information of the case studies.

Table 1: Summarized information of the case studies

\begin{tabular}{|c|c|c|c|c|}
\hline Premises & Khoo Kongsi & Cheah Kongsi & Teochew Temple & $\begin{array}{c}\text { Hock Teik Chen Shin } \\
\text { Temple }\end{array}$ \\
\hline Use of Premises & Clan house & Clan house & Clan house & Clan house \\
\hline No of Floors & 2 & 2 & 1 & 2 \\
\hline Approx. Age & Since 1851 & Since 1810 & Since 1869 & Since 1892 \\
\hline Approx. Age & Since 1851 & Since 1810 & Since 1869 & Since 1892 \\
\hline Area of building & $97,035 \mathrm{sq} \mathrm{ft}$ & $16,146 \mathrm{sq} \mathrm{ft}$ & $19,636 \mathrm{sq} \mathrm{ft}$ & $14,865 \mathrm{sq} \mathrm{ft}$ \\
\hline
\end{tabular}

\section{Data Analysis and Discussion}

\subsection{Fire Hazards}

After the fire risks assessments were carried out, it is found that the fire risk of the temples is mainly from the joss stick used to worship the ancestral. Besides, the fire hazards are more likely to come from the oil lamps where the posterities light up the oil lamps as to pray for good fortune. The storage management for combustible materials vary in each temples. Khoo Kongsi makes a good example in keeping them whereas Hock Teik Cheng Sin Temple are less aware of this issue. The combustible materials are not well kept as shown in Fig. 2. There should be a store to keep all the flammable materials in the temples.
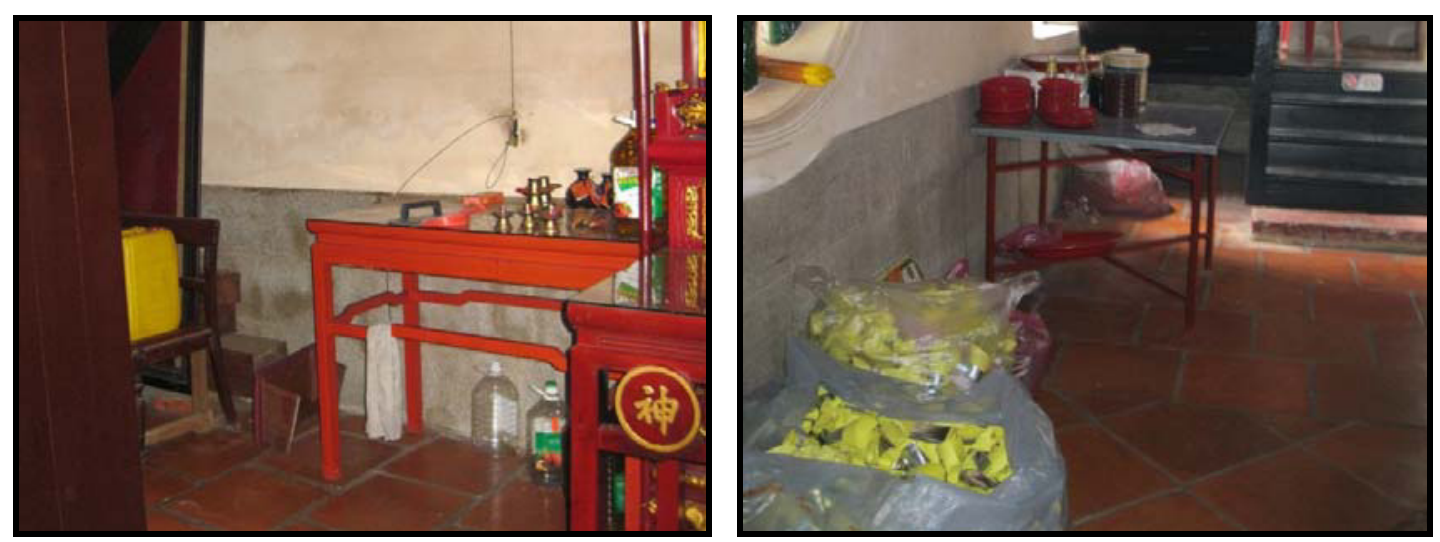

Figure 2: Oil for lamps and joss stick not well kept (left) and materials to worship not properly kept (right)

Fig. 3 shows a typical worship hall of these ancestral temples in Khoo Kongsi. It is clear that the area is made up almost $70 \%$ by timber. Timber is a highly flammable building material. Thus, the fire risks increased proportionally with the types of building materials. Nobody actually staying in four of the temples nowadays, thus there is no open flame and fire hazard from the kitchen as compared to old times. The main electrical installation and equipment are inspected occasionally, depending on situation of each temple. In preventing electrical fire, there is however, no testing procedure been carried out. 


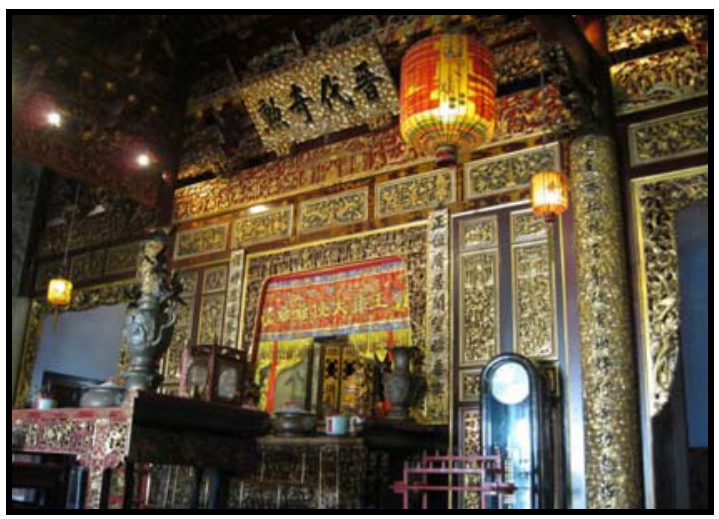

Figure 3: A typical worship hall of the ancestral temple at Khoo Kongsi

\subsection{General Health and Safety Management}

In health and safety management wise, the owner and authority of Khoo Kongsi are doing good job where the documentation of the health and safety policy of the temple is well kept although they do not have any specific officer solely in charge of it. There is however, no regular check on the fire safety inspection in all four temples. There is no designated competent person for health and safety areas, to comply with the requirement of the Management of Health and Safety at Work Regulation, which indicates the lower awareness in public risk and health factor. There is no proper risk assessments' documents for general work activities carried out within the building too, making the occupants of these temples are not well conscious of health and safety policy of the building.

\subsection{Staff Awareness and Training}

As far as we can establish, the occupants in the temples are aware of their responsibilities in the event of fire. They are alert of the escape route, the location of fire extinguishers and the structure of the building although there is not any training to cover all relevant fire related information and guidance to them. Basically, only staffs in Hock Teik Chin Seng Temple do not practice good housekeeping to prevent fire hazards and maintain safety standards. The flammable materials are not well kept in the temple and this should be taken seriously before any fire hits the temple. None of these temples carry out fire risks tests within the building as an effort to ensure employees are aware of the fire exits and action to take.

\subsection{Fire Fighting}

There are no emergency plans developed for these companies so that it would be available and easily reached by the staffs. The staffs awareness and training regarding fire risks are still very low in four of the temples. In Khoo Kongsi, there are several numbers of fire extinguishers placed around the building. A total number of 27 fire extinguishers recorded in here, with estimating RM1000 spent a year on their maintenance according to Account Admin, Ms Yeap Siok Ching. All of the fire extinguishers are placed in the worship hall at first floor and also the museum at ground floor. Cheah Kongsi and Teochew Temple has a total number of 10 and 13 fire extinguishers respectively, whereas Hock Teik Cheng Sin Temple does not install any fire extinguisher (Table 3). In Khoo Kongsi, there is a fire extinguisher which is located near to the location of a higher fire risk, which is the worship hall, where joss sticks and candles are often used. The portable fire extinguishers used are of correct type, which is Class A fire extinguisher. All the fire-fighting appliances certified by FRDM annually, with all of them properly colour- coded. 


\subsection{Fire Exit Routes and Signage}

Under UBBL clause 166, it states that every floor space shall be provided with at least two exits on the basis that if one exit is inoperable, the other exit can serve the function [13]. Every ancestral temple fulfilled this aspect because all of the temples have more than one excess to upper floor. It meets the requirement of to provide with at least two exits on the basis that if one exit is inoperable, the other exit can serve the function. However, the exits routes in these temples are not provided with conspicuous exit sign such as the "Green Running Man" on a white background. However, it is quite easy to escape from these temples as the points of exits from the building clear of obstructions. All floor surface and stairs on escape routes are free from tripping and slipping hazards [14]. However, the door used in all the ancestral temples are not fire rated door. This puts people in dilemma because when efforts are made to protect the heritage art and culture of the elements of these temples, we need to compromise a little with these art values. Lighting wise, it can be considered as satisfactory as all lighting (normal and where provided emergency) on escape routes are fully operational. However, to the needs of the disable, all the four temples have not provides mean of escape adequately for them. The escape routes of these ancestral buildings are by far satisfactory and they all leads in different direction to places of safety, as shown in Fig. 4, the open space in Cheah Kongsi.

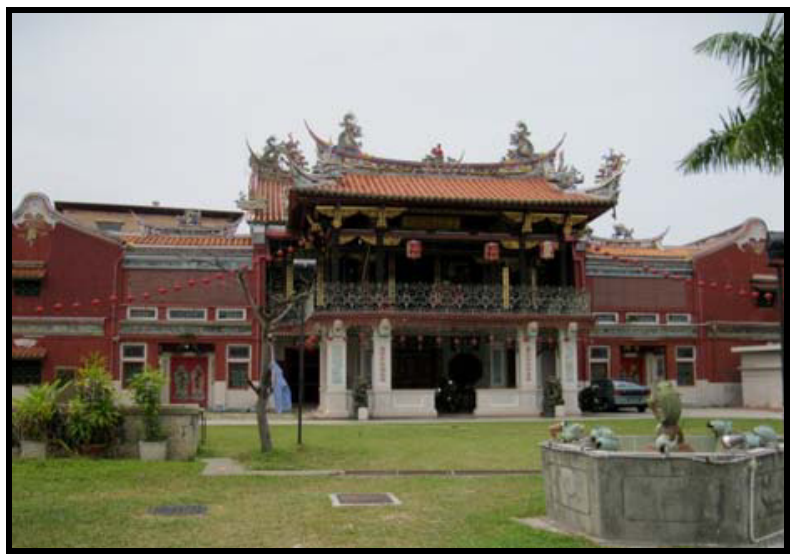

Figure 4: Large open space outside of Cheah Kongsi for mean of escape during fire outbreak.

\subsection{Fire Detection \& Alarm}

On fire detection and alarm observation, none of the temples surveyed have smoke / heat detectors fitted to the temple (Table 3). According to interviewed respondents, they are not aware of the types or usage of smoke / heat detectors thus there are no such equipments in the temples. Smoke detectors are advisable to be installed in all other location of the temples except the worship hall as there will often be smokes produced from the joss stick.

Table 3: Summarized of fire protection system practiced in the case studies

\begin{tabular}{|c|c|c|c|c|}
\hline Premises & Khoo Kongsi & Cheah Kongsi & $\begin{array}{c}\text { Penang Teow } \\
\text { Chew Assoc }\end{array}$ & $\begin{array}{c}\text { Hock Teik Cheng } \\
\text { Sin Temple }\end{array}$ \\
\hline Fire Extinguisher & 27 & 10 & 13 & 0 \\
\hline Smoke Detector & 0 & 0 & 0 & 0 \\
\hline Fire Route & YES & NO & NO & NO \\
\hline Annual fire protection cost & RM 1000 & RM 360 & RM 480 & RM 0 \\
\hline
\end{tabular}


Similarly, there is no fire call point (break glass) in the temples too. Another reason given was that all these temples are actually easy to escape to a safe open space in the case of emergency, therefore they reckon they do not need the fire alarms in their building. On the other hand, there is no hose reel found in all the four ancestral temples. This is due to the lack of UBBL practice in heritage buildings [15].

\subsection{Safety of Visitors and Contractors}

All the ancestral temples are open to public for visits, thus the fire safety of visitors should be taken into account. From the interviews done, it is clear that the safety precautions steps for visitors in the event of fire is not properly conducted or communicated. The contractors working in the temples are not obliged to prepare a standard operation procedure for the safety and fire risk issues for the temples, and this indicates a lack of communication of parties involved in handling this issue.

\section{Recommendations for Improvement}

\subsection{Life Safety}

Under life safety, all the four temples do not have any emergency lights and emergency exit sign. Although the elements could be a little odd to be installed in the heritage buildings, but it is necessary for the safety purpose of the visitors. It can help the visitors to identify the correct way to escape during a fire outbreak [12]. Besides, the corridor of the temples should be installed with some emergency lights. This is important especially during the fire outbreak. Every temple must come out with a complete instruction on what should we do if there is any fire risk outbreak happened. This can be a fire escape route or instruction, depending on the owner to decide. It is important to deliver the information on what to do during fire.

\subsection{Fire Prevention}

In fire prevention wise, it is recommended that the building install automatic fire detectors. (fire alarm system). An automatic fire alarm system which consists of interconnected devices and controls that is designed to detect the unwanted presence of fire by monitoring environmental changes associated with combustion [7]. Automatic fire alarm systems are intended to notify the building occupants to evacuate in the event of a fire or other emergency, to request such civil defence as fire brigades emergency services, and to send digital signals to associate systems interface to control the spread of fire and smoke. This is really helpful in preventing the fire outbreak as presence of any small fire will be directed to the authority.

\subsection{Fire Protection}

Discussing about the fire protection in the entire studied ancestral temples, the most important element that can be recommended is the compartmentalization. The spread of fire within a building can be restrained by sub-dividing it into compartments separated from one another by walls and/or floors of fire-resisting construction [11]. This method helps to prevent rapid fire spread which could trap occupants of the ancestral temples and to reduce the chance of fires becoming large, on the basis that large fires are more dangerous, not only to occupants but to people in the vicinity of the building. The construction of such compartments and all their components is a matter of systems within systems, which use bounding to achieve fire-resistance ratings, all interdependent, forming part of an 
overall fire safety plan. Compartmentalization prevents the spread of fire within the building and allows more time for fire suppression.

\subsection{Fire Fighting}

There are a few important elements under fire fighting facilities that are recommended to be installed in the ancestral temples. Portable fire extinguisher will be the most important one. So far in our observation, only Hock Teik Cheng Sin Temple does not provide any fire extinguisher. It should be pointed out that fire extinguisher should be installed near to the emergency staircase and the exit. There should be sufficient number of fire extinguishers in the temple. It is obvious that only Khoo Kongsi has fulfilled this requirement at the moment. Thus, it is advisable that other temple to fix a fire hydrant near to their premises. Depending on the size and location of the building and the provision of access for fire appliances, additional fire hydrant shall be provided as may be required by the Fire Authority. Sprinkler system is helpful in the entire ancestral temple too. All sprinkler systems shall be electricity connected to the nearest fire station to provide immediate and automatic relay of the alarm when activated.

\section{Conclusion}

It is clear that the ancestral temples in Georgetown, Penang are yet to achieve a high level of fire risk protection awareness. The fire risks are in moderate condition but it is obvious a lot more can be done to prevent the fire outbreak in these beautiful buildings. As to treasure the heritage values in the buildings, the efforts to protect them should be parallel with our love to these buildings. The fire protection systems practised in these buildings are still very limited whereas it is a very basic level where only fire extinguishers are provided. Fire hydrant can be found only in Khoo Kongsi, making people doubt the fire protection level of these buildings. Owners should aware that the buildings are made up of $70 \%$ timber, which is highly flammable. More precaution steps and actions should be done accordingly and not solely rely and limited to the fire extinguisher. The system should be reviewed.

In order to increase the fire protection in these ancestral temple, it is advisable that the owner seek some advises from the FRDM as there are no intrusion from the Fire and Rescue Department Malaysia in helping and consulting them on issues to increase the fire protection level in the buildings The buildings are under private property license, FRDM will never have authorized to intrude in the fire protection system unless the owners want them and requiring proper check and advices from the authority.

Thus, temple trustee and owners should put into consideration in inviting FDRM in their temple future development planning. In conclusion, there are still a lot to do to enhance the fire protection system in the ancestral temples in Georgetown, Penang. All the heritage elements in these building are so valuable that by which, overlooking the safety issues would jeopardize us on losing them in fire that can be avoided. A little more effort done today will surely makes things a lot different in the future.

\section{References}

1. Salleh, H.N., A.G. Ahmad, 2009. Fire Safety Management In Heritage Buildings: The Current Scenario In Malaysia, 22nd CIPA Symposium, pp: 4-6.

2. Norgaard, J., M.A. Othuman Mydin, 2013. Drywall Thermal Properties Exposed to High Temperatures and Fire Condition. Jurnal Teknologi, 62 (1): 63-68 
3. Ibrahim, M.N., K. Abdul-Hamid, M.S. Ibrahim, A. Mohd-Din, R.M. Yunus, M.R. Yahya, 2011. The Development of Fire Risk Assessment Method for Heritage Building. 2nd International Building Control Conference, 20: 317-324

4. Ramachandran, G., 1999. Fire Safety Management and Risk Assessment, Facilities, 17 (9/10): 363-367

5. M.A. Othuman Mydin, N. Md Sani, M. Taib, 2014. Industrialised Building System in Malaysia: A Review. MATEC Web of Conferences, 10: 01002, DOI: http://dx.doi.org/10.1051/matecconf/20141001002

6. Salleh, N.H., 2011. Fire Safety Management in Heritage Buildings: The Current Scenario in Malaysia. Published in CIPA 2009 at Kyoto, Japan

7. Chow, W.K., 2002. Proposed Fire Safety Ranking System EB-FSRS for Existing High-Rise NonResidential Buildings in Hong Kong. ASCE Journal of Architectural Engineering, 8 (4): 116-124

8. Bernama, Retrieved 10 April 2013. Fire destroys seven shops at Penang heritage site. http://thestar.com.my/news/story.asp?file=/2008/12/11/nation/20081211140318\&sec=nation

9. The Star, Retrieved 10 April 2012. Gambier Street shophouses destroyed in 2009 fire to be rebuilt, http://thestar.com.my/news/story.asp?file=/2012/10/14/sarawak/12168770

10. New Straits Times, Retrieved 10 April 2013. Fire razed 10 shophouses on Chap Goh Meh, http://www.nst.com.my/nation/general/fire-razed-10- shophouses-on-chap-goh-meh-1.224205

11. Zhao, C.M., S.M. Lo, J.A. Lu, Z. Fang, 2004. A Simulation Approach for Ranking of Fire Safety Attributes of Existing Buildings, Fire Safety Journal, 39: 557-579

12. Soleimanzadeh, S., M.A. Othuman Mydin, 2013. Influence of High Temperatures on Flexural Strength of Foamed Concrete Containing Fly Ash and Polypropylene Fiber, International Journal of Engineering, 26 (1): 365-374

13. S.W. Tan, M.A. Othuman Mydin, N. Md Sani and M.Z. Sulieman, 2014. Investigation into Common Decay of Educational Buildings in Malaysia. MATEC Web of Conferences, 10: 05001, DOI: http://dx.doi.org/10.1051/matecconf/20141005001

14. Nasiri, M, 2012. Skidding Routes Simulation for Opening Access to High-Risk Fire Areas. World Applied Sciences Journal, 16 (6): 791-798

15. Othuman Mydin, M.A., Y.C. Wang, 2011. Structural Performance of Lightweight Steel-Foamed Concrete-Steel Composite Walling System under Compression. Journal of Thin-walled Structures, 49 (1): 66-76 